Pécsi Tudományegyetem, Klinikai Központ, Fogászati és Szájsebészeti Klinika, Fogszabályozási Részleg*

Pécsi Tudományegyetem, Klinikai Központ, Fogászati és Szájsebészeti Klinika, Dentoalveoláris Részleg**

\title{
Lehetséges mellékhatások a fogszabályozó kezelések kapcsán
}

\author{
DR. GYÓCSI ANDRÁS*, DR. KOLAROVSZKI BÉLA**, DR. FRANK DOROTTYA*
}

\begin{abstract}
Jelen áttekintő közlemény célja, hogy a fogszabályozó kezelések során előforduló lehetséges mellékhatásokat összegezve részletes irodalmi összefoglalást nyújtson az esetlegesen kialakuló szövődményekről (fogágyat ért egészségkárosodás, külső gyökér resorptio, zománckárosodás, pulpát érintő változások, fájdalom, diszkomfort, lágyrészsérülések, készülékalkatrészek/műszerek légúti aspirációja/lenyelése, infektív endocarditis, temporomandibuláris ízületi problémák, allergiás reakciók). Minthogy a fent említett kedvezőtlen, nem kívánt mellékhatások jelentős része kellő figyelemmel és körültekintéssel megelőzhető, vagy a kialakulásuk kockázata minimálisra csökkenthető, ezen információk ismerete alapvető fontossággal bír minden egyes fogszabályozással foglalkozó gyakorló orvos vagy leendő szakorvos számára.
\end{abstract}

Kulcsszó: mellékhatás, fogszabályozó kezelés, káros, szövődmény

\section{Bevezetés}

Mint a legtöbb egészségügyi beavatkozás, így a fogszabályozó kezelések alkalmával is felléphetnek nem kívánt, káros hatások. Minden olyan az orvosi beavatkozások következtében fellépő egészségkárosodást, ami a szervezet valamilyen működési zavarát okozza és az elvégzett beavatkozással közvetlen okozati öszszefüggésben keletkezett a beteg állapotában, mellékhatásnak, szövődménynek tekinthetünk. $A$ beavatkozások esetében a legnagyobb körültekintés ellenére is fellépnek egészségügyi kockázatok. Ezeket a kezelés úgynevezett objektív mellékhatásainak tekintjük (genetikai hajlam, ismeretlen allergia). Ugyancsak adódhat egészségkárosodás a kezelő orvos hibájából, mint például diagnosztikus tévedések, mulasztások, kezelés alatti hiányosságok, nem megfelelő eszközökkel, illetve a megfelelő eszközök hiányában elvégzett beavatkozások. A szövődmények lehetséges kialakulásának harmadik nagy csoportját pedig azok a tényezők alkotják, melyek a páciens nem megfelelő együttműködésére vezethetők vissza, mint például a nem megfelelő szájhigiénia vagy a kontrollok elmulasztása. Természetesen a kiváltó tényezők legtöbbször együttesen vannak jelen és egymással szoros interakcióban állnak, utalva ezzel is gyakori multifaktoriális eredetükre. Minden páciensnek jogában áll a kezelés előtt a kezelő orvosától számára érthető módon felvilágosítást kapni. A tájékoztatáshoz való jog kivétel nélkül megilleti őket, melynek részletesen ki kell terjednie a beavatkozások kockázataira is, beleértve a lehetséges szövődmények előfordulási gyakoriságát is. A másik oldalról pedig az orvos is köteles eleget tenni ezen tájékozta- tási kötelezettségének, melynek legfőbb mércéje az elvárható gondosság elve. Közleményünk célja, hogy ezeket a mellékhatásokat összegezve egy áttekintő irodalmi összefoglalást nyújtson, mert ezen információk ismerete elengedhetetlen annak érdekében, hogy minden páciens az őt megillető lehető legmagasabb szintû ellátásban részesüljön.

\section{Lehetséges mellékhatások}

\section{Parodontális vonatkozások}

A parodontális szöveteket érintő megbetegedés az egyik leggyakrabban fellépő mellékhatása a fogszabályozó kezeléseknek. Legtöbbször plakk okozta gingivitis tünetekkel találkozunk, de a fogágybetegségek számos egyéb megjelenési formája is elófordulhat (parodontitis, alveoláris csontveszteség, dehiszcencia, fenesztráció, gingiva-hyperplasia, recesszió) [6]. Fogínyduzzanat rögzített készüléket viselő páciensek esetén mintegy 0,69\%-ban, míg fogínyvérzés átlagosan 58,72\%-ban alakul ki [44]. A kezelést követően pedig az esetek mintegy 10,3\%-ában fordul elő recesszió, elsősorban az alsó metszők területén [39]. A plakk okozta gingivitisek kiváltó tényezője a nem megfelelő szájhigiénia miatt felhalmozódó dentális plakk. A fogszabályozó kezelés során használt készülékalkatrészek önmagukban fokozott veszélyt jelentenek a plakkfelhalmozódás szempontjából, és bebizonyosodott, hogy nemcsak a plakk mennyisége, hanem annak minőségi összetétele is jelentősen megváltozik [38]. Minthogy a jó szájhigiénia alapvető kulcsa a parodontális egészségnek, a kezelés megkezdése előtt és annak teljes ideje alatt a pá- 
ciensek szájhigiénés instruálására, motiválására nagy hangsúlyt kell fektetni. Mindemellett fluorid, illetve klórhexidin tartalmú fogkrémek, szájvizek, szájápolási készítmények használata is ajánlott, melyek tovább csökkentik a plakk okozta megbetegedések kialakulásának esélyét [3]. A plakk mellett természetesen egyéb tényezők is befolyásolják a parodontális szövetek egészségi állapotát, mint például a dohányzás, a gazdaszervezet fogékonysága, szisztémás betegségek, illetve bizonyos gyógyszerek is. A hydantoin, cyclosporin A, kalciumcsatorna-blokkolók, antikoncipiensek és a korai generációs, magasabb hormontartalmú készítmények a legfontosabb gyógyszercsoportok, melyek hatással lehetnek a fogágy állapotára. Azoknál a pácienseknél, akiknél fokozott a rizikó - vagyis fennáll valamelyik fent említett tényező közül valamelyik vagy esetlegesen több -, illetve azoknál, akiknél a parodontális szövetek egészségi állapota károsult, fokozott figyelmet kell arra fordítani, hogy a fogágyat tovább ne károsítsuk. Gyakoribb kontrollok (általában 3 havonta parodontológiai szakrendelésen), professzionális szájhigiénés beavatkozások szükségesek, kisebb erők, illetve kevésbé plakkretentív alkatrészek használata. Az ilyen páciensek esetén kerülni kell az elasztikus ligatúrák alkalmazását, helyette inkább fém ligatúrák felhelyezése javasolt, melyek a plakkfelhalmozódás szempontjából lényegesen kedvezőbb feltételeket biztosítanak. Ugyancsak kerülendő a gyürűk ragasztása, gyürűk helyett pedig inkább ragasztható tubusok alkalmazása ajánlott. Azoknál a pácienseknél, akiknél fogágybetegség diagnosztizálható, kontraindikált a fogszabályozó kezelés megkezdése mindaddig, míg az aktív folyamatot nem állítottuk meg, és a páciens szájhigiénéje nem megfelelő.

\section{Külső gyökér resorptio}

A külső gyökér resorptio egyes szerzők szerint elkerülhetetlen velejárója a fogmozgatásnak. Mikroszkóppal vizsgálva a gyökérfelszínt Segal és mtsi 100\%-ban mutattak ki gyökérfelszívódást fogszabályozó kezelést követően [31]. Kurol és mtsi ugyancsak magas előfordulási arányt, mintegy 93\%-os gyakoriságot találtak [13]. Átlagosan mintegy 1,421+/-0,448 mm-rel rövidült a gyökér hossza a kezelések során [31]. Enyhébb esetek, ahol a $2 \mathrm{~mm}$-t nem haladja meg a resorptio mértéke átlagosan 5-18\%-ban, míg a súlyosabbak a gyökér hoszszának 1/3 és $4 \mathrm{~mm}$ közötti rövidülése ennél ritkábban 1-5\%-ban fordulnak elő [14]. Tünetekkel azonban még súlyosabb mértékű felszívódás esetén is csak ritkán találkozhatunk. A Miller-skála szerinti beosztás alapján 1. fokú fogmobilitás csak extrém ritkán fordul elő. Kalkwarf vizsgálatában arra a következtetésre jutott, hogy 3 mm-es felszívódás körülbelül $1 \mathrm{~mm}$-es tapadásvesztésnek felel meg [11]. A felszívódás súlyosságának megítélésére a Malmgren-féle beosztást használjuk, mely 5 csoportba sorolja a resorptiók típusát azok mértéke alapján (0-Nincs resorptio, 1-enyhe resorptio, a gyökérhossz változatlan, de szabálytalan kontúrlefutás, 2-mérsékelt resorptio, gyökércsúcs mérsékelt fel- szívódása, egyenes csúcsi lefutás, 3-fokozott resorptio, a gyökér 1/3-a felszívódott, 4-extrém resorptio, a gyökér több mint 1/3-a felszívódott) [18].

Az etiológiai tényezőket két nagy csoportra bonthatjuk; a páciens-függő, illetve a kezelés kivitelezéséhez kapcsolódó tényezők. A páciens-függő tényezők esetén alapvető feladatunk, hogy a magas rizikójú pácienseket még a kezelés előtt felismerjük és kiszűrjük. Ha már a kezelés előtt diagnosztizálható resorptio, ott a kezelés során a felszívódás nagy valószínűséggel tovább súlyosbodik. Ugyancsak különbségek vannak a különböző etnikai csoportok között is. Az ázsiai népcsoportoknál általában jóval kisebb mértékű felszívódás látható, mint a kaukázusi vagy a hispániai népcsoportoknál [14, 28]. Sameshima és munkatársai 868 páciens vizsgálata során azt tapasztalták, hogy a fent említett 3 népcsoportnál minden esetben a felső oldalsó metszők voltak legnagyobb mértékben érintve. Az ázsiaiaknál 0,97 +/-1,22, a kaukázusi csoport esetén 1,58+/-1,35, a hispániaiaknál pedig 1,65+/-1,27 mm mértékű resorptio volt átlagosan látható. A legkisebb mértékű felszívódást pedig az alsó metszők esetén mérték, ahol átlagosan az ázsiai népcsoportnál $0,61+/-0,90$, a kaukázusinál 0,65+/-0,96, még a hispániaiaknál 0,84+/-1,02 mm mértékű resorptiót diagnosztizáltak [28]. A páciensek általános állapota, egyes szisztémás betegségek (allergia, asthma, diabetes mellitus és egyes endokrin megbetegedések) szintén növelik a kockázatot. Az erupciós zavar a szomszéd fog gyökerére gyakorolt nyomás miatt ugyancsak rizikótényezőnek számít. A nyitott harapás is predisponálhat a gyökér hosszának megrövidülésére, ebben az esetben a nem megfelelően fejlett parodociumot tartják felelősnek, mert ez rosszul reagál a különböző ortodonciai erőkre. A hypodontia vagy egy korábban elszenvedett trauma szintén növeli a felszívódás kialakulásának esélyét [1]. Végül, de nem utolsó sorban a gyökérmorfológia is fontos szerepet játszik. A vékony, kúp alakú, gracilis, görbült gyökerek esetén nagyobb valószínúséggel kell számolni resorptióval. Az ortodonciai technikát magában foglaló rizikótényezők közé a kezelési idő hossza, a gyökér helyzetének változtatása, az alkalmazott erő típusa és nagysága tartoznak [31]. Mindezek közül a legjelentősebb hatással a kezelés időtartama bír. A legveszélyesebb fogmozgatási típusok közé az intrusio, illetve a vesztibuláris korona torque mozgatások tartoznak. Ugyancsak kerülendő a nagy és folyamatos, illetve váltakozó irányú erők alkalmazása. Amennyiben már a kezelés megkezdése előtt fény derül a fokozott rizikóhajlamra, kerülni kell a nagymértékű mozgatásokat, nagy erőket, minimalizálni szükséges a kezelési időt, illetve 6 havonta kontroll röntgenfelvételek elkészítése javasolt, legalább a frontfogak területéről. Amennyiben negatív a röntgenlelet és az elváltozás stagnál, úgy várhatóan nem lesz jelentősebb romlás a kezelés hátralevő részében. Abban az esetben, ha a resorptio egyértelmúen diagnosztizálható, esetleg fokozódott, akkor szükséges 2-3 hónapig passzív ív mentén pihentetni a fogmozgatást [42], 
illetve a kezelési célt újraértékelni. Legvégső esetben pedig akár a kezelés teljes megszakítása is alternatíva lehet. A kezelést követően is szükséges további követéses röntgenvizsgálat. Az 1. ábra egy többszörösen újrakezelt páciensről készült panoráma röntgenfelvételt szemléltet, melyen jó látható a kialakult resorptiók mértéke. Amennyiben a progresszió még a kezelés befejeztével is folyatódik, szükséges felülvizsgálni esetleges okklúziós trauma fennállását, illetve kizárni a retenciós készülék aktív állapotát.

\section{Zománckárosodás}

\section{Zománc demineralizáció, fogszuvasodás}

Szintén gyakori mellékhatása a fogszabályozó kezeléseknek a zománc demineralizáció - természetesen csak abban az esetben, ha a páciens szájhigiéniája nem megfelelő. A készülékalkatrészek jelentős mértékben fokozzák a plakkretenciót, és ezzel egy időben csökkentik az öntisztulás lehetőségét. Rögzített készülék mellett mintegy 2-3-szorosára növekszik a plakkretenció [12], továbbá megfigyelhető a nyál pH értékének csökkenése, illetve a Streptococcus mutans és a Lactobacillus számának emelkedése is [40]. Leggyakrabban a bracket bázisok körül, általában azok gingivalis és distalis szélénél láthatunk kialakult léziókat [8]. Elsősorban a felső metszőfogak érintettek, Chapman tanulmányában $30 \%$ fölötti előfordulást említ a frontrégióban [7]. A léziók kialakulásának megelőzése alapvető fontosságú. A prevenció legfontosabb alappillére a megfelelő szájhigiénia kialakítása, a táplálkozási tanácsadás; a páciens instruálása, motiválása. Ugyancsak javasolt kezelés előtt a páciens caries rizikóját felmérni. Amennyiben fokozott a rizikó, fontos a plakkretenciós tényezőket minimálisra csökkenteni. A felesleges ragasztócement precíz eltávolításával is tovább csökkenthetjük a retenciós tényezőket. A felesleges cement eltávolítást a színes ragasztóanyagok megjelenése jelentősen megkönnyítette. A fluorid tartalmú ragasztóanyagok használata tovább csökkenti a demineralizáció lehetőségét. A fluorid tartamú szájöblítők használata is tovább csökkenti a léziók kialakulását [2]. Ezek alapján a fluorid tartamú készítmények, fogpaszták, ecsetelők és szájvizek alkalmazása fontos részét képzi a prevenciónak [19]. A zománc savakkal szembeni ellenállóságát ugyancsak fokozhatjuk lézeres kezeléssel. Vizsgálatok igazolják, hogy a széndioxid, illetve Neodymium-Doped Yttrium Aluminium Garnet lézer - ez utóbbi a nedves szövetekbe történő jobb penetrációs képességének köszönhetően - hatékonynak bizonyult a zománc demineralizációval szembeni ellenállóbbá tételében [27]. Amennyiben a készülék eltávolítása után kerül sor a lézió diagnosztizálására, akkor az egyik lehetséges megoldás, hogy várunk a spontán remineralizációra, vagy a másik lehetőség, hogy remineralizációt segítő fluorid, illetve kazein-foszfopeptid tartalmú készítményeket alkalmazunk. Egyes esetek-

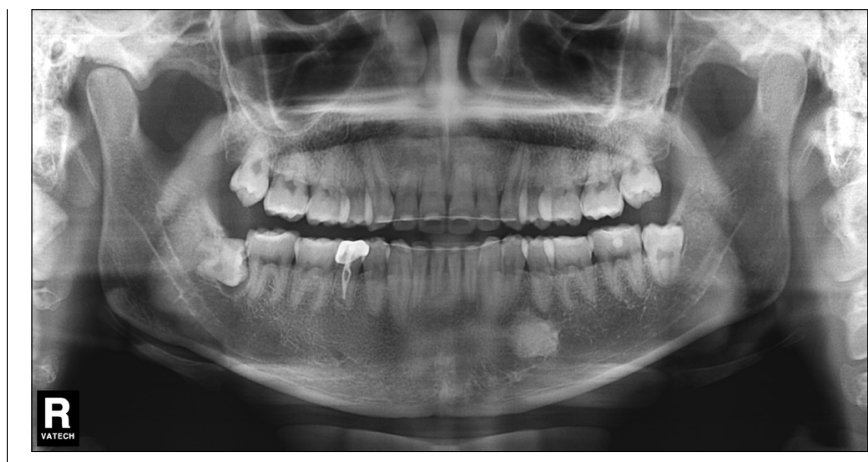

1. ábra: Egy többszörösen újrakezelt páciens panorámaröntgen-felvétele. A Malmgren-féle osztályozás szerinti enyhe, mérsékelt, illetve fokozott gyökérreszorpciók láthatók a front- és a premoláris fogak területén.

ben mikro abráziós vagy caries infiltrációs technikák is kiváló kezelési alternatívát jelenthetnek.

\section{Irreverzibilis zománckárosodás}

Az ortodonciai kezelések során kialakuló irreverzibilis zománckárosodás elsősorban a használt ragasztási és bracket eltávolítási technikától függ. Bizonyított, hogy a zománcfelszínhez történő ragasztás során a zománcfelszínen irreverzibilis változások mennek végbe, amely változások jóval jelentősebbek a hagyományos savbond rendszerek alkalmazása esetén [26]. A ragasztás során kialakuló úgynevezett rezin tagek keletkeznek, melyek a ragasztóerő nagyságát határozzák meg, azonban ezek maradéktalan eltávolítása szinte lehetetlen a zománc irreverzibilis károsítása nélkül. Az újabb, önsavazó rendszerek használatakor lényegesen kisebb károsodással kell számolnunk, azonban ezzel együtt természetesen csökken a ragasztóerő is. Fjeld és munkatársai 3 különböző típusú ragasztóanyag zománcra gyakorolt hatását vizsgálták. A konvencionális rezin tartamú bracket ragasztó, amennyiben azt 35\%-os foszforsavval együttes kondicionálással alkalmazták, okozta a legjelentősebb változásokat a zománcfelszínen. Mély és vastag, mintegy 10-20 $\mu$ m-es rezin tagek keletkeztek, melyek következtében szignifikánsan megnőtt a felszíni zománcegyenetlenség. Önsavazó rendszerrel kombinált rezintartalmú ragasztóanyagok esetén lényegesen kisebb, mintegy 5-10 $\mu \mathrm{m}$-es tagek alakultak ki. A legkedvezőbb eredményt a rezin módosított üvegionomer Fuji ORTHO LC esetén kapták, ahol a zománcfelszínt a ragasztás előtt 10\%-os poliakrilsavval előkezelték. Ez utóbbi esetben egyáltalán nem volt megfigyelhető tagképződés, így szinte minimális volt a zománcra gyakorolt károsító hatás [9]. A ragasztási technika mellett a debondig technika is alapvető jelentőséggel bír. A sérülés esélye a fém bracketek és üvegionomer alapú cementek együttes használata esetén a legminimálisabb. A sérülés kerámia bracketek esetén fokozódik, főleg ha hagyományos sav-bond technikát és rezin alapú ragasztót használunk. A sérülés elkerülése érdekében ezért eltávolításkor arra kell 
törekedni, hogy a bracketek és a ragasztóanyag közti kapcsolatot megszakítsuk, majd ezt követően a viszszamaradt ragasztót javasolt vídia keményfém fúróval körülbelül 30 000/perc-es fordulatszámon eltávolítani. Sigiliao és munkatársai további 6 különböző eltávolítási protokollt (forgó múszer finomság és fordulatszám szerint) összehasonlítva azt találták, hogy bár a vizsgált módszerek egyike sem növelte a felszíni érdességet, a ragasztóanyag eltávolítással töltött idő nagy jelentőséggel bír a sima zománcfelszín elnyerése tekintetében. Eredményeik alapján arra a következtetésre jutottak, hogy minél hosszabb ideig tart a maradék ragasztóanyag eltávolítása, az annál finomabb zománcfelszínt eredményezhet [33]. Mindemellett a zománcsérülések csökkentésére alternatív megoldás lehet a forgó múszerek helyett az intraoralis homokfúvó használata. Mhate és munkatársai azt találták, hogy a ragasztóanyag eltávolítása homokfúvóval jelentősen kíméletesebb volt, mint az alacsony fordulatszámú forgó müszer használata [17].

\section{Elszíneződések a fogakon}

A fogszabályozó kezelést követő zománc-elszíneződések meglehetősen kedvezőtlen esztétikai megjelenést kölcsönöznek, és negatív irányban befolyásolják a páciens kezeléssel kapcsolatos megítélését. Az elszíneződések etiológiai eredetüket tekintve multifaktoriálisak és gyakrabban fordulnak elő rögzített készülékes kezeléseknél [26]. A rezin tartalmú ragasztók használatakor a zománc-elszíneződések elkerülhetetlenek, ugyanis a kialakult rezin tageket a zománc károsodása nélkül nem lehet eltávolítani, ezért negatívan befolyásolják a zománc optikai megjelenését. Az elszíneződések hátterében leggyakrabban különböző ételszínezékek, ultraviola sugárzás állnak, és a készülék korróziója során kioldódó anyagok a felelősek. Az elszíneződések legtöbbje általában sárgás jellegű.

\section{Szekunder attríció, fogkopás}

A készülékalkatrészek nem megfelelő érintkezések mellett a fogakon szekunder kopási felszíneket alakíthatnak ki. A kerámia bracketek mintegy 9-38-szorosára emelik ennek esélyét a fém bracketekhez képest. Ebből adódóan kerülni kell a nem megfelelő érintkezéseket, hogy az irreverzibilis kopási felszínek kialakulását megelőzzük. Például azoknál a pácienseknél, akiknél mélyharapás látható, kerülni kell az - elsősorban kerámia - bracketek ragasztását az alsó metszőfogakon mindaddig, míg megfelelő vertikális, illetve sagittalis túlharapás mellett nem biztosítható a rendellenes kontaktusok kiküszöbölése.

\section{Diszkomfort, fájdalomérzet}

Átlagosan a páciensek mintegy 75-95\%-ánál jelentkezik valamilyen kellemetlen érzet, fájdalom a kezelés során [25]. Leggyakoribb a nyomó, feszítő, lüktető jellegü fájdalom. A frontfogaknál jóval gyakrabban számolnak be a páciensek fájdalomérzetről, mint a támasztó zónában [30], illetve elsősorban a rögzített készülékes kezelések kapcsán fordul elő. Irodalmi adatok szerint a készülék felhelyezését követően mintegy 4 óra után jelentkezik először a tünet, és akár 7 napig is eltarthat. 48 órával a kezdő ív behelyezését követően a legintenzívebb, ami az esetek mintegy $2 \%$-ában akár éjszakai alvási problémákat és fájdalomcsillapító használatát is eredményezheti [34]. A fájdalom elsősorban étkezések alkalmával okoz nehézségeket [8]. Enyhítésére speciális múanyag ostyát, esetleg aszpirin tartalmú rágógumit javasolnak egyes szerzők, mivel ez fokozza a parodontális szövetek vérkeringését, ezáltal csökkentve a fájdalomérzetet. Néhány esetben akár fájdalomcsillapító, elsősorban ibuprofen vagy acetaminofen tartalmú gyógyszerek alkalmazhatók a panaszok enyhítésére [24]. Sebészi beavatkozások kapcsán bebizonyosodott, hogy a félelem, illetve a szorongás szignifikáns hatással van a fájdalomérzékelésre [15]. A fogszabályozó kezelés előtti félelem és stressz ugyancsak szoros összefüggést mutatott a kezelés során fellépő fájdalomérzettel. Ebből adódóan a kezelés előtti tájékoztatás, a páciens felkészítése alapvető, mellyel oldani lehet a szorongását, és ezzel egy időben csökkenteni a kezelés során a fájdalom percepcióját [41].

\section{Infektív endocarditis}

A fogászati beavatkozások, így a fogszabályozó kezelések között is számos olyan létezik, melyek tranziens bakterémiát idéznek elő. Már a gyűrűfelhelyzést megelőző szeparálás során is számítani lehet átmeneti baktériumszám-növekedésre a véráramban. Ezen tranziens baktériumszám-fokozódás a gyűrüfelhelyezés során az esetek mintegy 10\%-ában fordul elő [16]. Mivel sok esetben a maxilla transzverzális tágításakor is olyan ragasztott készüléktípusokat alkalmazunk, melyek gyürük segítségével rögzülnek, ezért a rizikópácienseknél javasolt úgynevezett splint típusú ragasztott tágítókészüléket alkalmazni. Ugyancsak fokozott elővigyázatosságot igényel a skeletalis horgonylatok behelyezése [37]. Bár a fent említett beavatkozásoknál jóval ritkábban, de az interproximális zománcredukció során is előfordulhat tranziens bakterémia. Yagci és munkatársai 29 pácienst vizsgáltak, de mindösszesen csak 1 esetben tudtak sztrippeléssel összefüggésben bakterémiát kimutatni [43]. Természetesen minden egyéb vérzéssel járó, invazív beavatkozás során, mint például ortodonciai indikációval történt fogeltávolítás, valamint az ortognáth mútétek esetén is szükséges a megfelelő előkészületeket megtenni. Szerencsére ezen átmeneti bakterémiával járó beavatkozások esetén az ebből adódó életet veszélyeztető bakteriális endocarditis előfordulásának rizikója meglehetősen alacsony. Azonban, hogy ennek előfordulását a lehető legkisebbre csökkentsük, minden rizikópáciens esetén 
a fent említett beavatkozásoknál szükséges antibiotikus profilaxis alkalmazása.

\section{Lágyrészsérülések}

Ortodonciai kezelések kapcsán meglehetősen gyakran fordulnak elő különböző, a készülékalkatrészek által okozott, direkt kontaktus révén kialakuló, avagy az operátor nem megfelelő múszerhasználatából eredő lágyrésztraumák. A sérüléseket elhelyezkedés alapján két nagy csoportba lehet sorolni: intra- és extraoralis. Az intraoralis sérülések leggyakoribb formái közé a bucca, a nyelv, az ajak és a gingiván előforduló nyálkahártyaeróziók, ulcerációk tartoznak, melyek sok esetben társulnak kellemetlen diszkomfort és fájdalomérzettel. A 2. ábra egy lip bumper által, míg a 3. ábra egy húzórugó által okozott nyálkahártya-sérülést szemléltet. A sérülések elkerülése végett javasolt a bracketeken és a készülék sérülést okozó részein védőviasz használata, illetve bizonyos esetben a gyógyulás idejére a mobilis alkatrészek ideiglenes eltávolítása. Transpalatinalis ívek ugyancsak okozhatnak benyomatot a lágyrészeken, elsősorban a nyelven (4. ábra), melynek ijesztő meg-

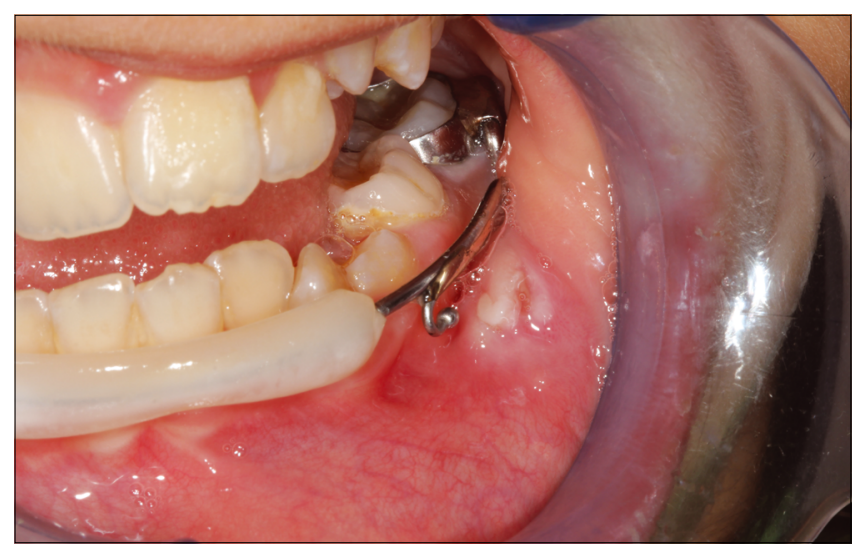

2. ábra: Lip bumber átal okozott intraorális lágyrészsérülés a bucca nyálkahártyán.

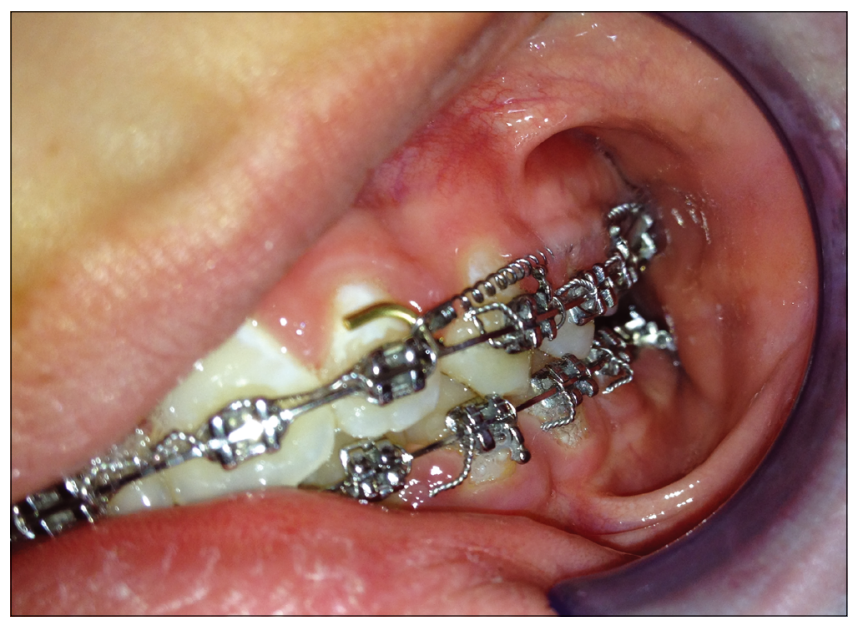

3. ábra: Gingivába besüppedt NiTi húzórugó.

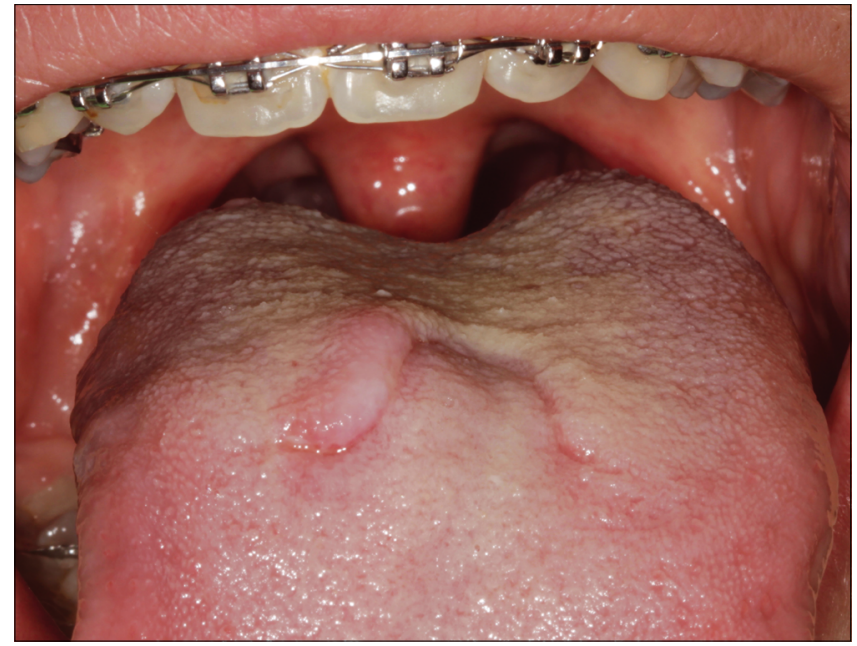

4. ábra: Transpalatinalis ív által okozott lágyrészbenyomat a nyelven.

jelenése szokott aggodalmat kelteni. Nemcsak intra-, hanem extraoralis sérülések is előfordulhatnak, elsősorban arcív használatakor. Ezek a traumás sérülések főként játékkal, alvással, vagy nem megfelelő használattal összefüggésben fordulnak elő. Blum-Hareuveni egyik közleményében például egy 12 éves fiú arcívvel szerzett szemsérülését mutatja be [4]. A sérülések elkerülése érdekében jelenleg az arcívek biztonsági zárakkal vannak ellátva.

\section{Pulpára gyakorolt hatások}

A fogszabályozó kezelés során történő fogmozgatás a fogbélre csak minimális hatással van, és elsősorban akkor is csak a kezelés legelején [34]. Főként enyhe, tranziens, gyulladásos reakció figyelhető meg, fokozott vascularisatio, az erekben felhalmozódott fehér és vörösvérsejtek, továbbá az odontoblast réteg megszakítottsága látható. Ezen morfológiai változások, illetve az enyhe pulpitises reakcióra emlékeztető tünetek szerepet játszhatnak a kezelés elején fellépő kellemetlen diszkomfortérzet kialakulásában is [29]. Vitalitásvesztés a fogmozgatások során csak ritkán fordul elő, melynek esélye a fogat ért korábbi traumák esetén, illetve nem megfelelő nagyságú erők alkalmazásakor, továbbá olyan irányú döntögető erők esetén fokozott, ahol a gyökércsúcs a corticalison kívülre mozdul, ezáltal a vérkeringés lehetetlenné válik [34].

\section{Temporomandibuláris ízületi probléma}

A tudomány jelenlegi állása szerint még mindig nem egyértelmúen bizonyított, hogy a temporomandibuláris ízületi problémák, illetve a malocclusio, és ennek megfelelően a fogszabályozó kezelések között szoros öszszefüggés lenne. A nemzetközi irodalomban számos, 
egymással ellentmondásban álló publikáció található. Egyes szerzők azon a véleményen vannak, hogy a kezelés során a korai fogérintkezések jelentősen megnövelik az ízületi panaszok előfordulását, míg mások úgy vélik, hogy nincs hatással rá [5]. Abban azonban egységes az álláspont, hogy minden kezelést megelőzően a klinikai vizsgálatnak az állkapocsízület alapos vizsgálatára is ki kell terjednie. Különösen fontos a korábbi fej-nyak területet ért trauma, gyulladásos eredetű csont és ízületi betegségek (rheumatoid arthritis), krónikus fejfájás, stresszes lelkiállapotok felderítése is, melyek hatással lehetnek az temporomandibuláris ízület állapotára. Azoknál a pácienseknél, akiknél ízületi probléma diagnosztizálható, a fogszabályozó kezelés megkezdése nem javasolt mindaddig, míg az ízületi panaszokat, diszfunkciót nem kezeljük.

\section{Idegentest légúti aspiráció, lenyelés}

A szájüregben történő manipuláció önmagában fokozott rizikót jelent a különböző meglazult, törött vagy nem megfelelően rögzített alkatrészek, múszerek légutakba, emésztőcsatornába kerülésére. Ezt a kockázatot a kis méret, a nyálas, csúszós környezet csak tovább növeli. A kialakult szövődmények nagymértékben függnek az idegen test alakjától, méretétől, és ebből adódóan annak elhelyezkedésétől. A légúti aspiráció lényegesen nagyobb veszélyt jelent, mint a gastrointestinalis lokalizáció. Tamura és mtsi egy Japánban végzett felmérés alapján arra a következtetésre jutottak, hogy a fogászati kezelések során mintegy 3,6-27,7\%-ban fordulnak elő ilyen jellegű balesetek. A gyakorisági sorrendben a protetikai beavatkozások után a fogszabályozó kezelések állnak a második helyen [35]. A balesetek megelőzése érdekében ezért javasolt például transpalatinalis ívek, quad helix esetén fogselyem felhelyezése behelyezéskor, illetve a készülék ligatúrával való rögzítése; ahol lehetséges az ívvégek lehajlítása; elszívó használata; készülék levételekor a bracketek ívvel együtt történő eltávolítása, illetve minden kezelés végeztével a szájüreg alapos átvizsgálása mozgó, leesett alkatrészek után [36]. Amennyiben a megfelelő óvintézkedések ellenére is bekövetkezik a baleset, azonnali elsősegélynyújtás és sürgősségi orvosi ellátás szükséges. Az észrevétlenül maradt aspirációkra azonban lehetséges, hogy csak később a már kialakult komplikáció, szövődmény hívja fel a figyelmet - pneumónia, bronchiectasia. Az ilyen esetekben a már kialakult granulációs szövet, hegesedés pedig tovább nehezíti az idegentest eltávolítását.

\section{Allergiás reakciók}

A fogszabályozó kezelések során leggyakrabban a nikkel, kobalt, króm, latex és a polimerek válthatnak ki allergiás reakciókat, melyek számos formában jelentkezhetnek - a lokális tünetként fellépő arc-nyaki bőr kontakt dermatitisétől kezdve egészen a súlyos szisztémás reakciókig. A leggyakoribb problémát a nikkel jelenti, mely jellemzően késői, IV. típusú hyperszenzitivitási reakciót vált ki. A leggyakoribb panaszok közé a szájégés tartozik, de emellett fémes íz, gingivitis, gingiva hyperplasia, angularis chelitis, labialis desquamatio, periodontitis, perioralis dermatitis, kontakt dermatitis és ritka esetben akár orolingualis parestesia is felléphet [23]. Számos szerző vizsgálta a nikkel és a króm kioldódását a különböző ortodonciában használt fémekből. Park és Shearer átlagosan mintegy $40 \mu \mathrm{g}$ nikkel és mintegy $36 \mu \mathrm{g}$ króm kiáramlást mért [21]. Shenkutvan és mtsi is vizsgálták a különböző ortodonciai ívekből történő nikkel-kioldódást, azonban a kioldódás mértéke egyik esetben sem haladta meg a napi élelmiszerbevitellel történő nikkelbevitel mennyiségét, tehát minden egyes esetben a kritikus érték alatt maradt, ami allergiás reakció kiváltásához még nem elegendő [32]. Egyes szerzők így úgy vélik, hogy sok esetben a nikkel nem önmagában, hanem más fémekkel együtt fejt ki allergiás reakciót, illetve érzékenyíti a gazdaszervezetet egy gyulladásos válaszreakción keresztül, így az fogékonyabb lesz különböző fogágybetegségekkel és nyálkahártya-elváltozásokkal szemben [22]. Ugyancsak bizonyított, hogy a korábbi nikkel expozíció, nikkel tartalmú ékszerek, piercingek viselése megnöveli a tünetek kialakulásának esélyét [10]. A megfelelő anamnézis elengedhetetlen a szövődmények elkerülése érdekében. Ismert nikkelallergia esetén választható alternatívák ívek esetén: rost-megerősítésű kompozit, TMA, tiszta titánium, aranyozott, múanyag borítású NiTi, ionkezelt NiTi ívek (az ívek felszínét nitrogénnel kezelik, mely amorf szerkezetű felszíni réteget képez az íven, ezáltal növeli a korróziós ellenállást és csökkenti az allergizáló hatást). A hagyományos bracketek helyettesítésére ajánlott kerámia, múanyag, polikarbonát, titánium vagy arany bracketek használata. A latex allergizáló hatása is nagy jelentőséggel bír. A teljes lakosság mindösszesen csak 1\%-át érinti, azonban a fogászati szakdolgozók és fogorvosok körében lényegesen magasabb arányban, mintegy 5\%-ban fordul elő [34]. A latex tartalmú kesztyűk mellett az elasztikus ligatúrák, a különböző extra- és intraoralis gumihúzáshoz használt elasztikus elemek válthatnak ki allergiát, mely általában ugyancsak IV. típusú, de legsúlyosabb esetben akár I. típusú hyperszenzitivitási reakcióként is jelentkezhet. Spina bifida, illetve korábbi sebészeti beavatkozások, melyeknél hosszabb latexexpozíció történt, jelentősen növelik az allergiás tünetek fellépésének esélyét [34].

\section{Összefoglalás}

A fogszabályozó kezelések során is sokszor kell kedvezőtlen mellékhatásokkal számolni. Ugyanakkor a legtöbb esetben ezek kellő odafigyeléssel elkerülhetők, vagy a kialakulásuk esélye minimálisra csökkenthető. 
Ehhez azonban fontos mind az orvos, mind a páciens számára a lehetséges összes kellemetlen következmény pontos ismerete. A páciensek teljes körű tájékoztatása még a kezelés előtt a kezelő orvos feladata. A pácienseknek átfogó tájékoztatást kell kapniuk a lehetséges szövődményekről, továbbá nyomatékosítani szükséges saját szerepvállalásuk, együttmüködésük fontosságát is annak érdekében, hogy a káros mellékhatásokat megelőzzük. Mindezek együttes figyelembevételével lehetséges a kezelési eredmény maximalizálása, a mellékhatások minimalizálása.

\section{Irodalom}

1. Artun J, Van 't Hullenaar R, Doppel D, Kuijpers-Jagtman AM: Identification of orthodontic patients at risk of severe apical root resorption. Am J Orthod Dentofacial Orthop. 2009; 135(4): 448-455.

2. Benson Pe, Parkin N, Millett DT, Dyer F, Vine S, Shah A: Fluorides for the prevention of white spots on teeth during fixed brace treatment. Cochrane Database of Systematic Reviews. 2004; No. 3 , CD003809.

3. Beyth N, Redlich M, Harari D, Freidman M, Steinberg D: Effect of sustained-release chlorhexidine varnish on Streptococcus mutants and Actinomyces viscous in orthodontic patients. Am J Orthod Dentofacial Orthop. 2003; 123: 345-348.

4. Blum-Hareuveni T, Rehany U, Rumelt S: Blinding endophthalmitis from orthodontic headgear. New England Journal of Medicine. 2004; 351(26): 2774-2775.

5. Bourzgui F, Sebbar M, Nadour A, Hamza M: Prevalence of temporomandibular dysfunction in orthodontic treatment. Int Orthod. 2010; 8(4): 386-398.

6. Bragger U, LANG N: Significance of bone in periodontal disease. Semin Orthod. 1996; 2: 32-38.

7. Chapman JA, Roberts We, Eckert GJ, Kula KS, González-Cabezas C: Risk factors for incidence and severity of white spot lesions during treatment with fixed orthodontic appliances. Am J of Orthod Dentofacial Orthop. 2010; 138(2): 188-194.

8. Firestone A, Scheurer P, Burgin, W: Patients' anticipation of pain and pain-related side effects, and their perception of pain as a result of orthodontic treatment with fixed appliances. Eur J Orthod. 1999; 21: 387-396.

9. FJeLD M, ØGAARD B: Scanning electron microscopic evaluation of enamel surfaces exposed to 3 orthodontic bonding systems. Am J Orthod Dentofacial Orthop. 2006; 130(5): 575-581.

10. Fors R, Persson M, Bergström E, Stenlund H, Stymne B, StenBERG B: Lifestyle and nickel allergy in a Swedish adolescent population: effects of piercing, tattooing and orthodontic appliances. Acta Derm Venereol. 2012; 92(6): 664-668.

11. KalkWARF KL, KREJCI RF, PaO YC: Effect of apical root resorption on periodontal support. J Prosthet Dent. 1986; 56(3): 317-319.

12. Klukowska M, Bader A, Erbe C, Bellamy P, White DJ, Anastasia MK, WeHrBein H: Plaque levels of patients with fixed orthodontic appliances measured by digital plaque image analysis. Am J Orthod Dentofacial Orthop. 2011; 139(5): 463-470.

13. Kurol J, Owman-Moll P, Lundgren D: Time-related root resorption after application of a controlled continuous orthodontic force. Am J Orthod Dentofacial Orthop. 1996; 110(3): 303-310.

14. Lopatiene K, Dumbravaite A: Risk factors of root resorption after orthodontic treatment. Stomatologija. 2008; 10(3): 89-95.

15. Malmo RB, Shagass C: Physiologic studies of reaction to stress in anxiety and schizophrenia. Psychosom Med. 1949; 11: 9-24.

16. Mclaughlin Jo, Coulter WA, Coffey A, Burden DJ: The incidence of bacteremia after orthodontic banding. Am J Orthod Dentofacial Orthop. 1996; 109(6): 639-644.
17. Mhatre aC, Tandur AP, Reddy SS, Karunakara BC, Baswaraj H: Enamel Surface Evaluation after Removal of Orthodontic Composite Remnants by Intraoral Sandblasting Technique and Carbide Bur Technique: A Three-Dimensional Surface Profilometry and Scanning Electron Microscopic Study. J Int Oral Health. 2015; 7(Suppl 2): 34-39.

18. Malmgren O, Goldson L, Hill C, Orwin A, Petrini L, Lundberg M: Root resorption after orthodontic treatment of traumatized teeth. Am J Orthod. 1982; 82(6): 487-491.

19. Ogaard B, Alm A, Larsson E, Adolfsson U: A prospective, randomized clinical study on the effects of an amine fluoride/stannous fluoride toothpaste/mouthrinse on plaque, gingivitis and initial caries lesion development in orthodontic patients. Eur $J$ Orthod. 2006; 28: 8-12.

20. Ogaard B, FJeld M: The Enamel Surface and Bonding in Orthodontics. Semin Orthod. 2011; 16(1); 37-48.

21. PARK HY, SheARER TR: In vitro release of nickel and chromium from stimulated orthodontic appliances. Am J Orthod. 1983; 84: 156-159.

22. Pazzini Ca, Junior Go, Marques ls, Pereira CV, Pereira LJ: Prevalence of nickel allergy and longitudinal evaluation of periodontal abnormalities in orthodontic allergic patients. Angle Orthod. 2009; 79: 922-927.

23. Pazzini CA, Marques lS, Pereira LJ, Corrêa-Faria P, Paiva SM: Allergic reactions and nickel-free braces: a systematic review. Braz Oral Res. 2011; 25(1): 85-90.

24. Polat O, Karaman A: Pain control during fixed orthodontic therapy. Angle Orthod. 2005; 75: 210-215.

25. Polat O: Pain and discomfort after orthodontic treatment. Semin Orthod. 2007; 13: 292-300.

26. Preoteasa CT, Ionescu E, Didilescu aC, Melescanu-Imre M, Bencze MA, Preoteasa E: Undesirable dental hard tissue effects hypothetically linked to orthodontics - a microscopic study. Rom J Morphol Embryol, 2011; 52(3): 937-941.

27. SadR HaghighI H, Skandarinejad M, Abdollahi AA: Laser application in prevention of demineralization in orthodontic treatment. $J$ Lasers Med Sci. 2013; 4(3): 107-110.

28. SAMESHIMA GT1, SINCLAIR PM: Predicting and preventing root resorption: Part I. Diagnostic factors. Am J Orthod Dentofacial Orthop. 2001 May; 119(5): 505-110.

29. Santamaria M Jr, Milagres D, Iyomasa MM, Stuani MB, Ruellas AC: Initial pulp changes during orthodontic movement: histomorphological evaluation. Braz Dent J. 2007; 18(1): 34-39.

30. Scheurer P, Firestone A, Burgin W: Perception of pain as a result of orthodontic treatment with fixed appliances. Eur J Orthod. 1996; 18: 349-357.

31. Segal GR, Schiffman PH, Tuncay OC: Meta analysis of the treatment-related factors of external apical root resorption. Orthod Craniofac Res. 2004; 7(2): 71-78.

32. Shenkutvan RS, Jacob S, Charles A, Vadgaonkar V, Jatol-Tekade S, GANGURDE P: Evaluation of nickel ion release from various orthodontic arch wires: An in vitro study. J Int Soc Prev Community Dent. 2014; 4(1): 12-16.

33. Sigilião lC, Marquezan M, Elias CN, Ruellas AC, Sant'Anna EF: Efficiency of different protocols for enamel clean-up after bracket debonding: an in vitro study. Dental Press J Orthod. 2015 Oct; 20(5): 78-85.

34. TALIC NF: Adverse effects of orthodontic treatment: A clinical perspective. Saudi Dent J. 2011; 23(2): 55-59.

35. Tamura N, Nakaulma T, Matsumoto $\mathrm{S}$, Ohyama T, Ohashi Y: Foreign bodies of dental origin in the air and food passages. Int J Oral Maxillofac Surg. 1986; 15(6): 739-751.

36. Umesan UK, Chua KL, Balakrishnan P: Prevention and management of accidental foreign body ingestion and aspiration in orthodontic practice. Ther Clin Risk Manag. 2012; 8: 245-252.

37. UYSAL T, YaGCI A, ESEL D, Ramoglu SI, KilinC A: Investigation of bacteremia following insertion of orthodontic mini-implants. World J Orthod. 2010; 11(4): 357-361. 
38. Van Gastel J, Quirynen M, Tenghles W, Carels C: The relationships between malocclusion, fixed orthodontic appliances and periodontal disease. A review of the literature. Aust Orthod J. 2007; 23: 121-129.

39. Vasconcelos G, Kuellsen K, Preus H, Vandevska-Radunovic V, HANSEN BF: Prevalence and severity of vestibular recession in mandibular incisors after orthodontic treatment. Angle Orthod. 2012 Jan; 82(1): 42-47.

40. ViziTIU TC, IONESCU E: Microbiological changes in orthodontically treated patients. Therapeutics, Pharmacology and Clinical Toxicology. 2010; 14(4): 283-286.

41. Wang J, Tang $X$, Shen $Y$, Shang G, Fang L, Wang R, Xu Y: The correlations between health-related quality of life changes and pain and anxiety in orthodontic patients in the initial stage of treatment. Biomed Res Int. 2015; 2015: 725913.

42. Weltman B, Vig KW, Fields HW, Shanker S, Kaizar EE: Root resorption associated with orthodontic tooth movement: a systematic review. Am J Orthod Dentofacial Orthop. 2010; 137(4): 462476.

43. Yagci A, Uysal T, Demirsoy KK, Percin D: Relationship between odontogenic bacteremia and orthodontic stripping. Am J Orthod Dentofacial Orthop. 2013; 144(1): 73-77.

44. Zanatta FB, Ardenghi TM, Antoniazzi RP, Pinto TM, Rösing CK Association between gingivitis and anterior gingival enlargement in subjects undergoing fixed orthodontic treatment. Dental Press J Orthod. 2014 May-Jun; 19(3): 59-66.

\section{Gyócsı A, Kolarovszki B, Frank D}

\section{Adverse effects of orthodontic treatments}

Orthodontic therapy, like any other medical intervention, in addition to its benefits carries the risk of potential complications and is associated with adverse effects-including periodontal problems, external root resorptions, pulpal changes, enamel damages (demineralization, discoloration, attrition), temporomandibular disorders, infective endocarditis, soft tissue damages, discomfort, pain and the risk of either aspiration or indigestion of medical instruments and appliances. Usually these effects are multifactorial in origin- most often a result of interactions between the patient, the dental practitioner and the technical aspects of the appliances or techniques. With preventive measurements and care, most of these complications can be either limited or completely avoided. Therefore, every dental practitioner must be fully aware of these effects and associated risk factors in order to maximize the treatment outcome. The present review aims to summarize these effects of orthodontic therapies, and provide a detailed description of factors and preventive measures, in order to minimize these damages.

Keywords: adverse effects, orthodontics, root resorption, peridontal problem, enamel damage 